\title{
Microstructural Characterization of a Magnesium Alloy Processed by Equal Channel Angular Pressing
}

\author{
Caracterización microestructural de una aleación de magnesio \\ procesada por presión en canal angular de sección constante
} Caracterização microestrutural de uma liga de magnésio
processada por pressão em canal angular de secção constante

\section{Abstract}

Samples of as-extruded ZK60 magnesium alloy were subjected to 6 passes of equal-channel angular pressing (ECAP) following route A. The processing temperature was decreased with the number of passes. The structural evolution of the deformed samples was analyzed using Electron Backscattered Diffraction (EBSD) and X-Ray Diffraction. The grain boundary misorientation distribution showed a reduction in the grain size accompanied by a large proportion of high angle grain boundaries and the presence of recrystallization processes. XRD results showed that with the increment of the applied strain the peaks presented a slight variation of the angles.

Keywords: ECAP, Equal-channel angular pressing, ZK60 as-extruded magnesium alloy, EBSD, Electron BackScattered Diffraction, XRD, X-Ray Diffraction.

\section{Resumen}

Muestras de una aleación extruida de magnesio ZK60 se sometieron a 6 pases de presión en canal angular de sección constante (ECAP), siguiendo la ruta A. La temperatura de procesamiento fue disminuida con el número

\footnotetext{
* Ph.D. Instituto Nacional de Investigación y Desarrollo para la Protección del Medio Ambiente (Bucarest, Rumania). dianadumitru1986@yahoo.com ** Ph.D. Instituto Nacional de Investigación y Desarrollo para la Protección del Medio Ambiente (Bucarest, Rumania). moncea.andreea@gmail.com *** Ph.D. Universidad Tecnológica de Pereira (Pereira-Risaralda, Colombia). osfahico@gmail.com
} 
de pasadas. La evolución estructural de las muestras deformadas, se analizó mediante Difracción de Electrones Retrodispersados (EBSD) y Difracción de Rayos X (DRX). La distribución de desorientaciones de los límites de grano (misorientation), mostró una reducción en el tamaño de grano, acompañado de una gran proporción de límites de grano de ángulo grande y la presencia de procesos de recristalización. Los resultados de la XRD, mostraron que con el incremento de la deformación aplicada, los picos presentan una ligera variación en los ángulos.

Palabras clave: ECAP, Presión en canal angular de sección constante, ZK60, Aleación extruida de magnesio, EBSD, Difracción de Electrones Retrodispersados, XRD, Difracción de Rayos X.

\section{Resumo}

Amostras de uma liga extrudida de magnésio ZK60 se someteram a 6 passos de pressão em canal angular de secção constante (ECAP), seguindo a rota A. A temperatura de processamento foi diminuída com o número de passadas. A evolução estrutural das amostras deformadas se analisou mediante Difração de Eléctrones Retrodispersados (EBSD) e Difração de Raios X (DRX). A distribuição de desorientações dos limites de grão (misorientation) mostrou uma redução no tamanho de grão, acompanhado de uma grande proporção de limites de grão de ângulo grande e a presença de processos de recristalização. Os resultados da DRX mostraram que com o incremento da deformação aplicada, os picos apresentam uma ligeira variação nos ângulos.

Palavras chave: ECAP, Pressão no canal angular de secção constante, ZK60, Liga extrudida de magnésio, EBSD, Difração de Elétrons Retrodispersados, DRX, Difração de Raios X. 


\section{INTRODUCTION}

Lately, due to its low density $\left(1.74 \mathrm{~g} / \mathrm{cm}^{3}\right)$ and relatively high specific strength, magnesium has attracted the attention of the investigators, offering the possibility to reduce structural weight by replacing steel and aluminium parts in the transportation industry. The ecological objective of the weight reduction is a decrease in fuel consumption and, consequently, lower production of $\mathrm{CO}_{2}$ emissions. Although magnesium and its alloys offer a remarkable potential in this context [1], most current applications involve only cast components [2], due to the poor formability and limited ductility of magnesium alloys at ambient temperature.

Due to the hexagonal close-packed (HCP) crystal structure, the low formability of magnesium alloys at room temperature requires grain refinement, as magnesium alloys with fine-grained structures become much more workable at slightly elevated temperatures such as $150-250{ }^{\circ} \mathrm{C}[3,4]$.

Lately, severe plastic deformation (SPD) techniques have been used to refine the grain structure of different materials. As plastic deformation is introduced without changes in the cross-section of samples, these techniques differ from conventional forming operations. Therefore, the process can be repeated indefinitely, leading to large amounts of imposed deformation and grain refinement [5]. Equal channel angular pressing (ECAP) is one of the most effective SPD techniques to achieve ultrafine grains of relatively large volumes of metals and alloys $[5,6]$. Improvements of ductility, strength and superplasticity were reported on steels, aluminum, copper and various magnesium alloys processed by ECAP [7-9].

The ECAP process entails the pressing of a billet through a die with two channels, which have similar cross-section and intercept at a certain angle, $\Phi[10$, 11]. As the billets processed by ECAP retain their cross section geometry, due to the ECAP die design, it is possible to repeat the process for a number of passes to refine the grains. By multiple passings, very large redundant strain and effective deformation can be developed in a bulk product. Also in ECAP, it is possible to rotate the billet around its longitudinal axis between successive passes to create different routes, such as route $A$, which denotes no sample rotations between passes, route $B_{A}-90^{\circ}$ back-and-forth rotations, route $\mathrm{B}_{\mathrm{C}}$ corresponding to continuous $90^{\circ}$ rotations, and route $\mathrm{C}$, which refers $180^{\circ}$ rotations [6].

Due to the low formability of magnesium alloys, the ECAP processing is carried out at elevated temperatures and therefore the grain refinement can be achieved by dynamic recrystallization. During the recrystallization process, the average grain diameter will approach a constant steady-state value.

The aim of the present study is to investigate the structural characterization of a magnesium alloy (ZK60) after being processed by ECAP. As recrystallization has an influence on the grain size, the development of the different recrystallization processes was also investigated.

\section{EXPERIMENTAL PROCEDURE}

The experimental material was a commercially ZK60 magnesium alloy (Mg-5.49Zn-0.55Zr, wt. \%), received in the form of an extruded bar, as the extruded ZK60 provides a fine grain size and is a favorable starting material for mechanical properties improved through grain refinement and precipitation hardening.

Billets were machined from the extruded rod into tetragonal specimens with dimensions of $10 \mathrm{~mm} \mathrm{x}$ $10 \mathrm{~mm}$ x $40 \mathrm{~mm}$. The ECAP process was carried out using a tool steel die with the internal angle, between the two channels, equal to $90^{\circ}$ and an external angle of approximately $16^{\circ}$, involving a strain of $\varepsilon \sim 1.07$ per pass, according to the relationship proposed by Iwahashi [12]. The specimens were deformed following a $180^{\circ}$ back-and-forward rotation of the billet, along the transverse axis, by rotating the die $90^{\circ}$ between each pass, which is equivalent to the socalled route A according to Valiev et al. [6]. As it can be seen in Figure 1, with this type of processing route, for each ECAP pass the entry and exit channels are reversed. 

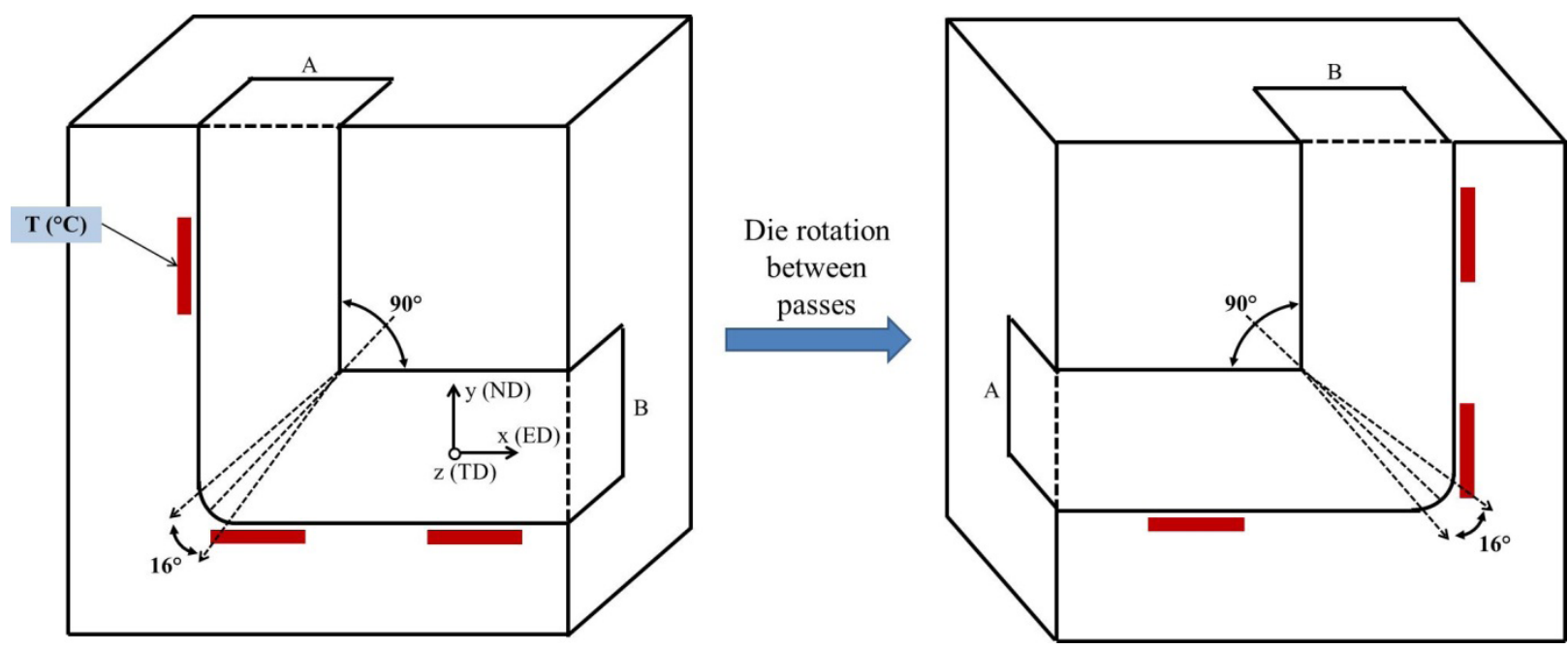

Fig. 1. ECAP die schematic and the applied route

The ZK60 magnesium alloy was processed until 6 ECAP passes. For the first 4 passes, the processing temperature was $250 \pm 5^{\circ} \mathrm{C}$, and starting with the 5 th pass, the processing temperature was decreased, using $200 \pm 5^{\circ} \mathrm{C}$ for the fifth ECAP pass and $150 \pm 5$ ${ }^{\circ} \mathrm{C}$ for the sixth pass. Prior to each pass, the samples were preheated to the temperature at which the ECAP process was conducted. The ECAP processing temperature was monitored through a thermocouple plugged to a multimeter placed near the plane of intersection of the two channels, as presented in Fig. 1. Each sample was kept in the die for 5 minutes, until the processing temperature was reached throughout the sample. Then the sample was ECAPed, and afterwards each sample was left to cool down to room temperature. $\mathrm{A} \mathrm{MoS}_{2}$ lubricant and back-pressure (by using aluminium samples) was assured in order to reduce friction.

The microstructure of the samples was characterized by Electron Backscattered Diffraction (EBSD) on the transversal plane, after each sample was mechanically polished, using standard metallographic procedures until $0.02 \mu \mathrm{m}$ colloidal silica suspension followed by electropolishing in a Struers AC2 solution, composed of $65-85 \%$ ethanol, $5-20 \%$ propanol, $<10 \%$ quinolinol, $<10 \%$ citric acid and $<5 \%$ distilled water.

The prepared samples were analyzed with a ZEISS Ultra Plus SEM, operating at $20 \mathrm{kV}$, equipped with an EBSD orientation imaging system. The Oxford Instruments HKL Channel 5 software package was used to process the obtained results. Different step sizes of $0.5 \mu \mathrm{m}$ (as-received ZK60 alloy), $0.2 \mu \mathrm{m}$ (between 1 and 4 passes), and $0.1 \mu \mathrm{m}$ (after 5 passes) were used. For this study, the misorientations lower than $2.5^{\circ}$ were not considered in the post processing data procedure, and the low angle grain boundaries (LAGB) were defined as misorientation angles between $2.5^{\circ}$ and $15^{\circ}$, while high-angle grain boundaries (HAGB) were defined when misorientation angles were greater than $15^{\circ}$.

The phase composition was analyzed on a D8 DISCOVER X-ray diffractometer (XRD) with $\mathrm{Cu} \mathrm{Ka}$ radiation, using a $0.04^{\circ}$ diffraction angle interval.

\section{RESULTS AND DISCUSSION}

In Figure 2, the optical microstructure and grain boundary distribution map, misorientation distribution and XRD pattern are presented. The high angle grain boundaries (HAGBs) are shown as blue lines, and low angle grain boundaries (LAGBs) as red lines.

The microstructure of the as-received ZK60 alloy is heterogeneous, being mostly composed by slightly equiaxed coarse grains, which present an average grain size of $37 \mu \mathrm{m}$, along with very fine recrystallized grains/subgrains $(2-3 \mu \mathrm{m})$ on several grain boundaries (Fig. 2b). The grain boundaries misorientation distribution (Fig. 2c) indicated for the correlated distribution a high proportion ( $53 \%)$ of LAGB. 
The X-ray diffraction analysis (Figure 2d) determined that the second phase particles, generally located at grain boundaries, represent both a Mg-Zn phase, as well as a $\mathrm{Zn}-\mathrm{Zr}$ phase, as mentioned in a previous investigation [13].
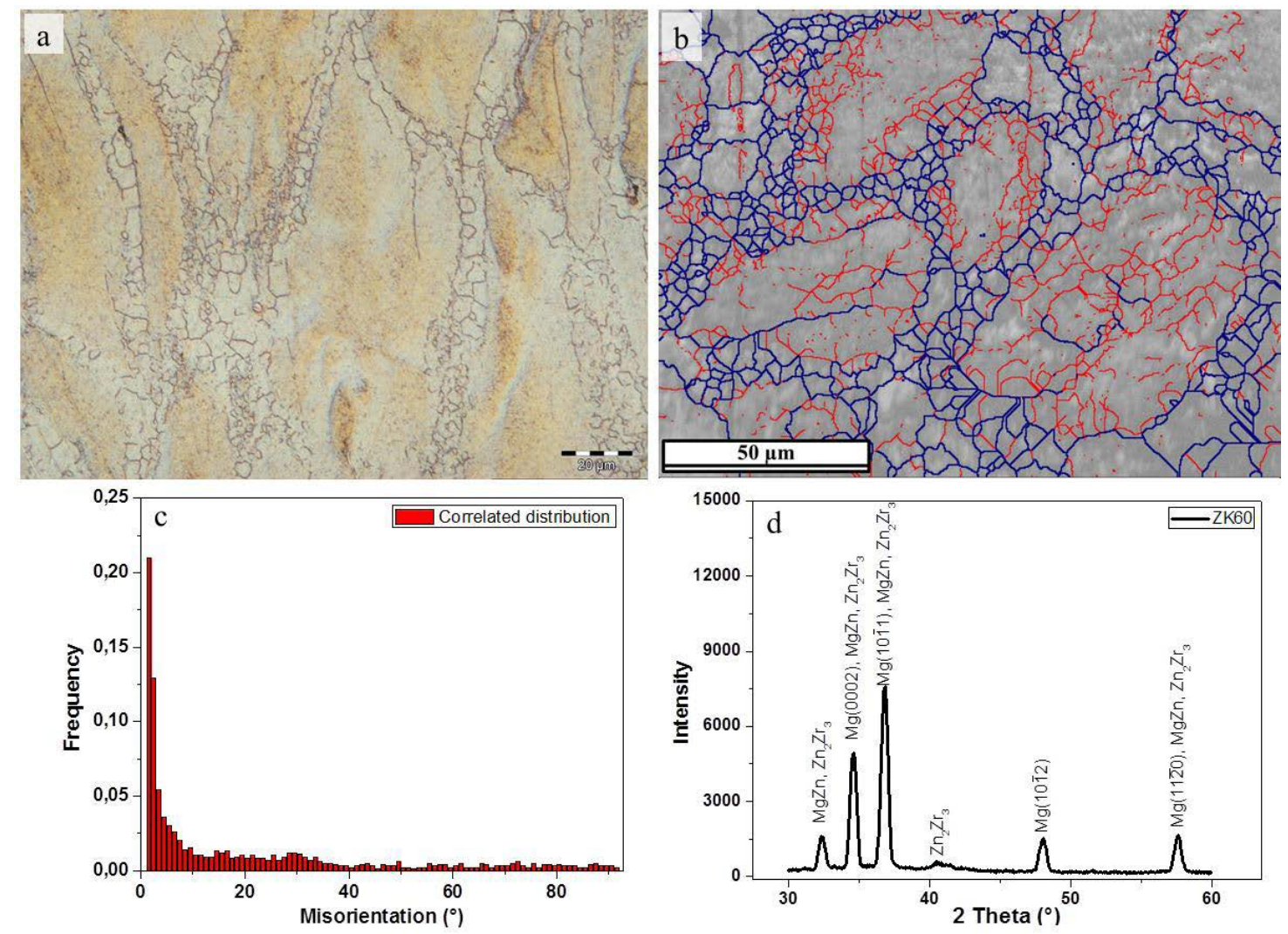

Fig. 2. Microstructure (a), grain boundary distribution (b), misorientation distribution (c) and XRD pattern (d) of the as-received ZK60 alloy

Although coarse grains are still visible after the first two ECAP passes, an obvious grain refinement may be observed (Figure $3 a$ and $3 b$ ). The heterogeneous microstructure seen in the as-received material persists, presenting a bimodal grain size distribution, with an approximate grain size of $27.8 \mu \mathrm{m}$ for the coarse grains and $1.7 \mu \mathrm{m}$ for the fine grains/subgrains, in the second pass. Also, the small recrystallized grains can generally be observed on grain boundaries of primary grains along with the presence of deformation twins develop during deformation at the temperature of 250 ${ }^{\circ} \mathrm{C}$.

The refinement continues in the third pass (Figure 3c), as the structure presents more homogeneous grains. It can also be noticed that after 4 ECAP passes (Figure 3d) the average grain size of the coarse grains slightly increases, reaching $20.4 \mu \mathrm{m}$, due to recrystallization and to a rapid grain growth [14], caused by the relatively high processing temperature and the interpass time. 

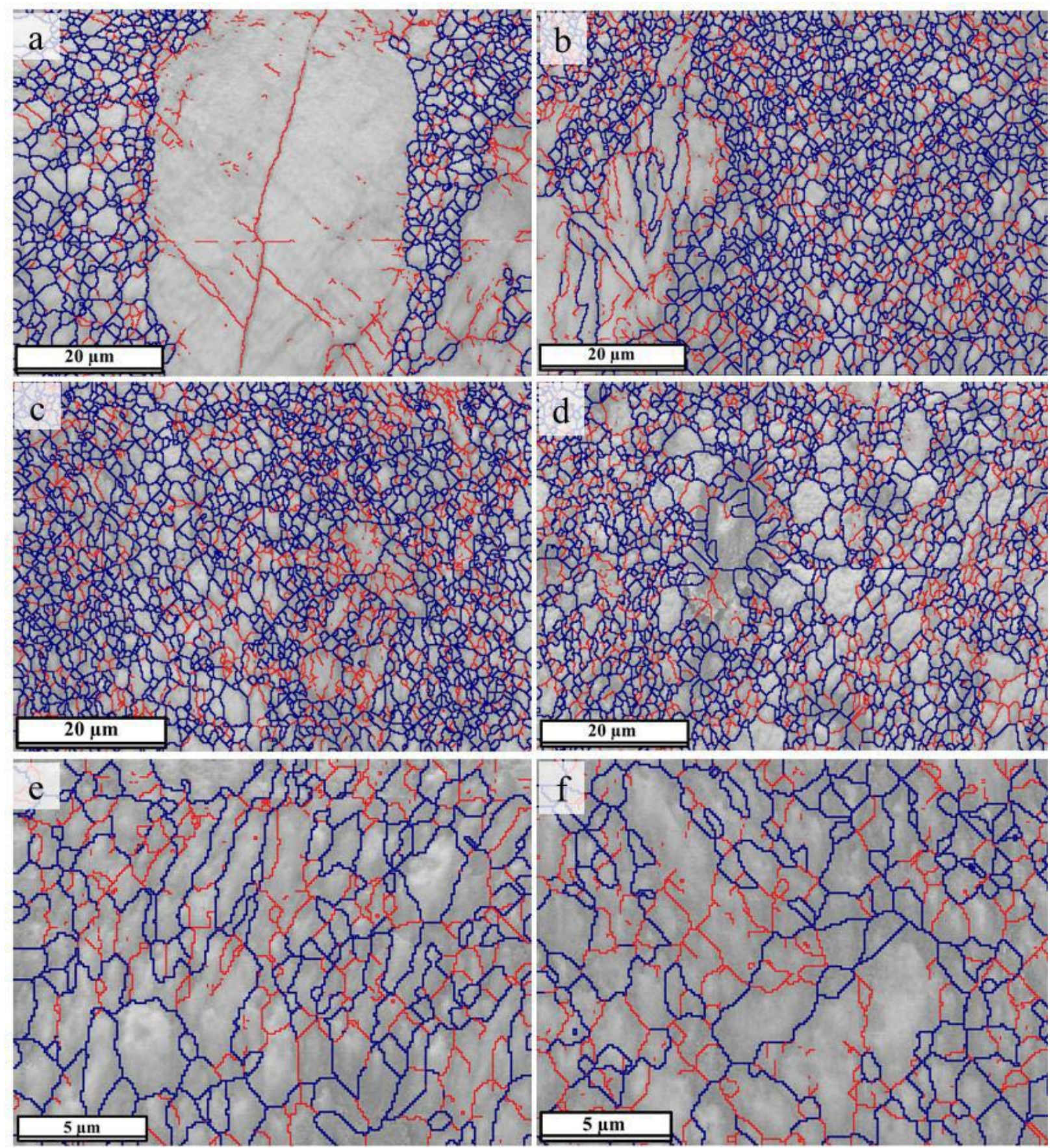

Fig. 3. Grain boundaries maps of ZK60 alloy processed by ECAP after: (a) 1 pass, (b) 2 passes, (c) 3 passes, (d) 4 passes, (e) 5 passes and (f) 6 passes 
It can be noticed that the recrystallized fraction is substantially higher than after the first pass, and the average size of the recrystallized grains is larger $(\sim 2$ $\mu \mathrm{m}$ ). With increasing the strain, until $\sim 6$ (Figure $3 \mathrm{e}$ and $3 \mathrm{f}$ ), a further grain refinement can be observed at a lower processing temperature than in the first 4 passes, reaching a value of $1.5 \mu \mathrm{m}$ for the fine recrystallized grains/subgrains. However, for the fifth ECAP pass, the structure is composed of grains elongated in the extrusion direction. The newly formed recrystallized fine grains consumed the original deformed microstructure.

It was observed that the recrystallization process occurs at the boundaries and consists of dynamic recrystallization, which occurs during the ECAP process at elevated temperatures, but also by metadynamic and static recrystallization, both occurring during the interpass time interval [15].
Regarding the misorientation distribution (Figure 4), the correlated distribution was determined, which represents an analysis of the misorientation between adjacent pairs of neighbors. A transition from LAGBs to HAGBs can be seen, as after deformation by ECAP, the presence of intensity peaks corresponding to special limits is noticed $\left(86^{\circ}\langle 11 \overline{2} 0\rangle, 56^{\circ}\right.$ $\left.\langle 11 \overline{2} 0\rangle, \quad 38^{\circ}\langle 11 \overline{2} 0\rangle \quad[16]\right)$ influencing the dynamic recrystallization process. The twin density and the consequent fraction of recrystallized grains rises as the strain increases due to the high nucleation rates of both twinning and recrystallization, resulting in a relatively homogeneous microstructure with ultrafine grains [17], as shown in the microstructure of the third ECAP pass.

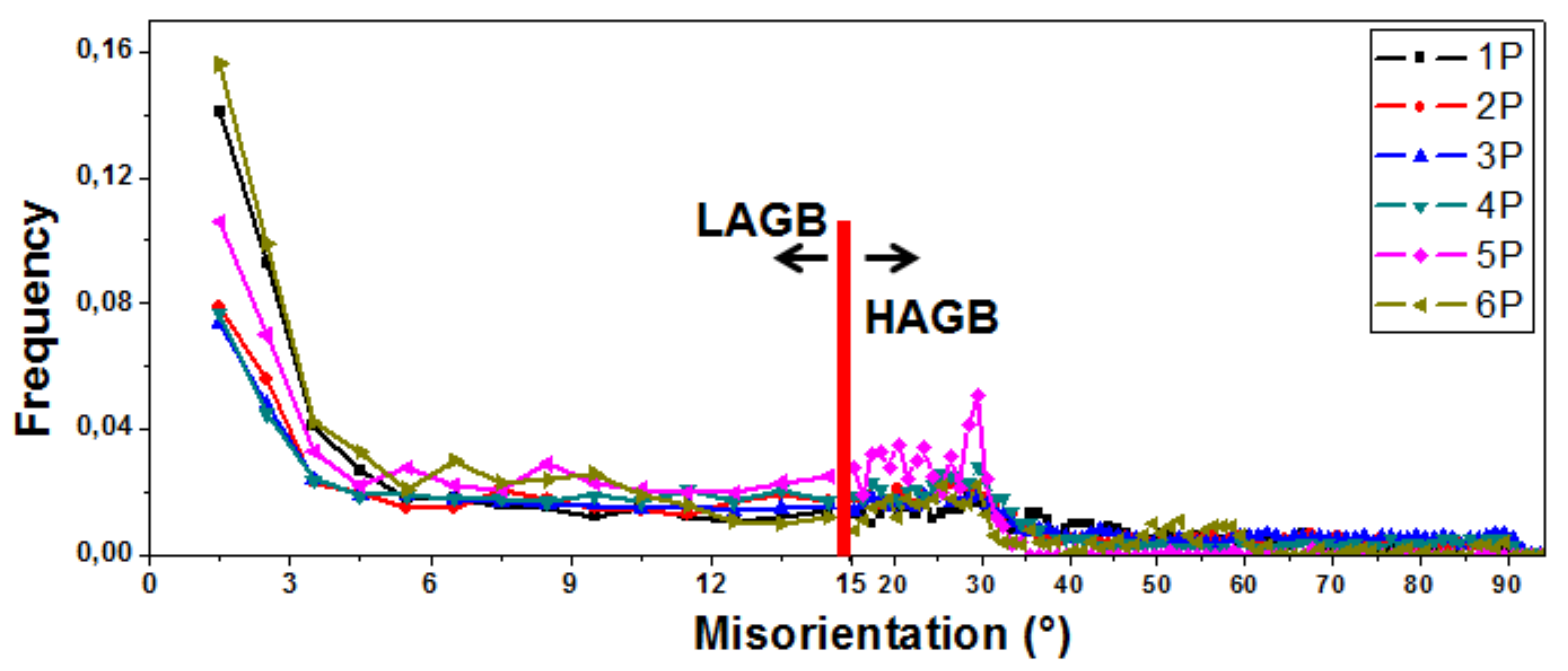

Fig. 4. Misorientation distribution for ZK60 alloy processed by ECAP 


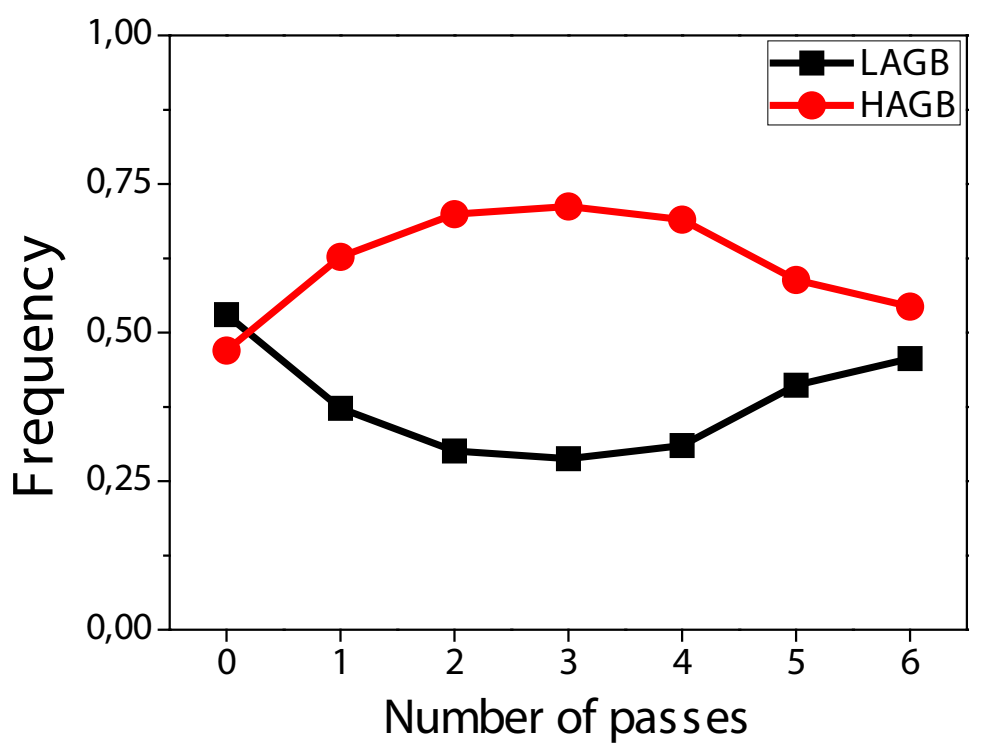

Fig. 5. Misorientation grade of the grain boundaries with the number ECAP passes

In Figure 5, the proportion of high/low angle grain boundaries was quantified. As it can be seen in the as received magnesium alloy, there is a high proportion of LAGBs, an indication that the structure of the initial material is formed by subgrains in a high proportion. However, with the amount of strain applied the proportion of HAGBs increases, reaching a value of $\sim 71 \%$ after the 3 th ECAP pass. This behavior is explained by the fact that when deformation reaches a sufficiently high value, dynamic recrystallization starts where high misorientations have been created by accumulation of dislocations, i.e. where slip has occurred on several slip systems (near grain boundaries and twins). The new fine grains form a mantle (necklace) along grain boundaries and deform more easily than the grain core, thus repeatedly undergoing recrystallization. With the additional strain induced and with the lowering of the processing temperature, the proportion of LAGBs slightly increases until the sixth ECAP pass.
Figure 6 presents the X-ray diffraction patterns of the severely deformed ZK60 alloy up to 6 passes. It can be noticed that the peaks show a slight variation of the angles, which can be caused by the applied strain [13]. It can be noted that with the increase in strain the peaks lose their intensity. An increment in the intensity of the peak corresponding to $\mathrm{Mg}(0002)$ until the fourth ECAP pass followed by a decrease in the intensity, but also fluctuations in the intensity of the peaks for $\operatorname{Mg}(10 \overline{1} 1), \operatorname{Mg}(10 \overline{12})$ and $\operatorname{Mg}(11 \overline{2} 0)$ can be noticed, suggesting changes in the different textures developed during ECAP following the alternative route A. The prismatic and pyramidal slip can be activated due to the behavior of grain boundaries [18], especially due to the presence of twin boundaries. The precipitated phases $\left(\mathrm{MgZn}\right.$ and $\mathrm{Zn}_{2} \mathrm{Zr}_{3}$ ) show fluctuations in the intensity at $\sim 33^{\circ}$ and $\sim 35^{\circ}$, which can be correlated to precipitate orientation. 


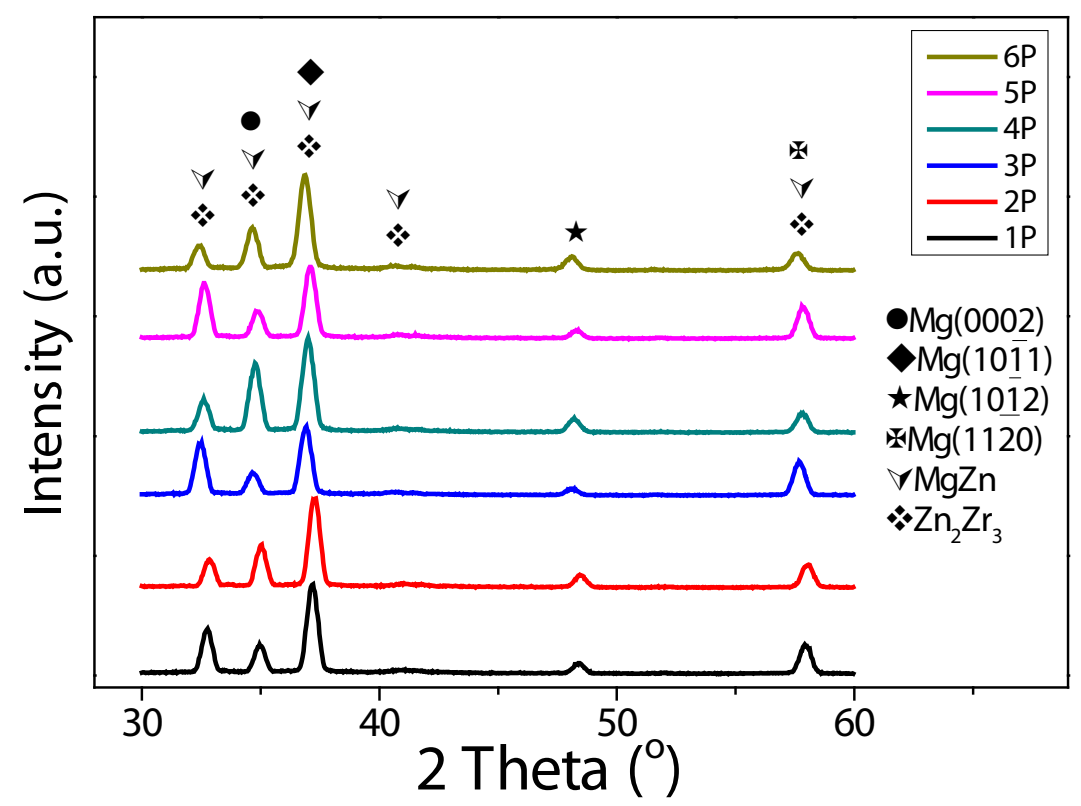

Fig. 6. XRD pattern diffractions of the ZK60 alloy processed by ECAP [13]

\section{Conclusions}

Through EBSD technique, a heterogeneous structure for the as-received ZK60 alloy was determined. The starting material was composed by slightly equiaxed coarse grains and fine recrystallized grains/subgrains situated on grain boundaries. This type of bimodal microstructure persisted within the first 2 ECAP passes, although the grains present an obvious grain refinement correlated with a large fraction of high angle boundaries. However, due to recrystallization and to a rapid grain growth after the fourth ECAP pass, the coarse grains slightly increase and thus the proportion of LAGB increases.

The second phase particles (Mg-Zn and $\mathrm{Zn}-\mathrm{Zr}$ phase) were generally located at grain boundaries. With the increase in strain some of the diffraction peaks lost their intensity, while others (such as $\mathrm{Mg}(0002)$, $\operatorname{Mg}(10 \overline{1} 1), \operatorname{Mg}(10 \overline{1} 2)$ and $\operatorname{Mg}(11 \overline{2} 0))$ presented fluctuations in the intensity of their peaks.

\section{ACKnowledgements}

Authors thank the CTM Technological Centre (Manresa, Spain) for the support given in the microstructural characterization.

\section{REFERENCES}

[1] H. Friedrich, S. Schumann, Journal of Materials Processing Technology 117 (2001): 276-281.

[2] B. Closset, Magnesium: Present and Future Opportunities, in: Proceedings of the 2nd International Light Metals Technology Conference, 2005, pp. 9-13.

[3] K. Matsubara, Y. Miyahara, Z. Horita, T. G. Langdon, Acta Materialia 51 (2003): 30733084 .

[4] Y. N. Wang, C. J. Lee, H. K. Lin, C. C. Huang, J. C. Huang, Materials Science Forum 426-432 (2003): 2655-2660.

[5] R. Z. Valiev, R. K. Islamgaliev, I. V. Alexandrov, Progress in Material Science 45 (2000): 103189.

[6] R. Z. Valiev, T. G. Langdon, Progress in Material Science 51 (2006) 881-981.

[7] R. K. Islamgaliev, N. F. Yunusova, R. Z. Valiev, N. K. Tsenev, V. N. Perevezentsev, T. 
G. Langdon, Scripta Materialia 49 (2003): 467472.

[8] M. Kawasaki, T. G. Langdon, Journal of Materials Science 42 (2007): 1782-1796.

[9] R. B. Figueiredo, T. G. Langdon, Materials Transactions 50 (2009): 111-116.

[10] V. M. Segal, Materials Science and Engineering A 197 (1995): 157-164.

[11] V. M. Segal, Materials Science and Engineering A 271 (1999): 322-333.

[12] Y. Iwahashi, Z. Horita, M. Nemoto, T. G. Langdon, Acta Materialia 45 (1997): 47334741 .

[13] F.-D. Dumitru, N. Ghiban, G. Gurău, U.P.B. Scientific Bulletin, Series B 75 (2013): 201208.
[14] Y. He, Q. Pan, Y. Qin, X. Liu, W. Li, Y. Chiu, J. J. J. Chen, Journal of Alloys and Compounds 492 (2010): 605-610.

[15] F.-D. Dumitru, O. F. Higuera-Cobos, J. M. Cabrera, Materials Science and Engineering A 594 (2014): 32-39.

[16] S. Biswas, S. S. Dhinwal, S. Suwas, Acta Materialia 58 (2010): 3247-3261.

[17] S. Q. Zhu, H. G. Yan, J. H. Chen, Y. Z. Wu, J. Z. Liu, J. Tian, Scripta Materialia 63 (2010) 985988.

[18] J. Koike, T. Kobayahsi, T. Mukai, H. Watanabe, M. Suzuki, K. Maruyama, K. Higashi, Acta Materialia 51 (2003): 2055-2065. 